\title{
MANGANESE AS ESSENTIAL AND TOXIC ELEMENT FOR PLANTS: TRANSPORT, ACCUMULATION AND RESISTANCE MECHANISMS
}

\author{
R. Millaleo ${ }^{1}$, M. Reyes-Díaz ${ }^{2}$, A.G. Ivanov ${ }^{3}$, M.L. Mora ${ }^{4}$, and M. Alberdi ${ }^{4 *}$ \\ ${ }^{1}$ Programa de Doctorado en Ciencias de Recursos Naturales, Universidad de La Frontera, Casilla \\ 54-D, Temuco, Chile. ${ }^{2}$ Center of Plant-Soil Interaction and Natural Resources Biotechnology, \\ Scientific and Technological Bioresource Nucleus (BIOREN), Universidad de La Frontera, \\ Casilla 54-D, Temuco, Chile. ${ }^{3}$ Department of Biology and the Biotron, University of Western \\ Ontario, London, Ontario, N6A 5B7 Canada. ${ }^{4}$ Departamento de Ciencias Químicas, Center of \\ Plant-Soil Interaction and Natural Resources Biotechnology - Scientific and Technological \\ Bioresource Nucleus (BIOREN), Universidad de La Frontera, Casilla 54-D, Temuco, Chile. \\ *Corresponding author: malberdi@ufro.cl
}

\begin{abstract}
Manganese is an essential element for plants, intervening in several metabolic processes, mainly in photosynthesis and as an enzyme antioxidant-cofactor. Nevertheless, an excess of this micronutrient is toxic for plants. Mn phytotoxicity is manifested in a reduction of biomass and photosynthesis, and biochemical disorders such as oxidative stress. Some studies on Mn toxicity and Mn translocation from soil to plant cells in $\mathrm{Mn}^{2+}$ form have demonstrated their importance under low $\mathrm{pH}$ and redox potential conditions in the soil. When $\mathrm{Mn}$ is inside the cells, mechanisms that can tolerate this toxicity are also observed, being important the compartmentalization of this metal in different organelles of shoot and leaf plant cells. A key role of antioxidative systems in plants in relation to high Mn amounts has also been reported as a defense mechanism. The purpose of this review is to show the role of $\mathrm{Mn}$ as an essential micronutrient and as a toxic element to higher plants as well as to their transport and tolerance mechanisms. The forms and dynamics of this element in soils and the importance of the acidity for this dynamic and availability for plants are also given.
\end{abstract}

Keywords: Manganese, Mn toxicity, resistance mechanisms

\section{INTRODUCTION}

Manganese (Mn) is an essential micronutrient in most organisms. In plants, it participates in the structure of photosynthetic proteins and enzymes. Its deficit is dangerous for chloroplasts because it affects the water-splitting system of photosystem II (PSII), which provides the necessary electrons for photosynthesis (Buchanan, 2000). However, its excess seems also to be particularly damaging to the photosynthetic apparatus (Mukhopadhyay and Sharma, 1991). Thus, Mn has two roles in the plant metabolic processes: as an essential micronutrient and as a toxic element when it is in excess (Kochian et al., 2004; Ducic and Polle, 2005). Mn toxicity is favored in acid soils (Pendias and Pendias, 1992). With decreasing $\mathrm{pH}$, the amount of exchangeable manganese mainly $\mathrm{Mn}^{2+}$ form - increases in the soil solution. This $\mathrm{Mn}$ form is available for 
plants and can be readily transported into the root cells and translocated to the shoots, where it is finally accumulated (Marschner, 1995). In contrast, other forms of $\mathrm{Mn}$ predominate at higher $\mathrm{pH}$ values, such as Mn (III) and Mn (IV), which are not available and cannot be accumulated in plants (Rengel, 2000).

Excessive Mn concentrations in plant tissues can alter various processes, such as enzyme activity, absorption, translocation and utilization of other mineral elements $(\mathrm{Ca}, \mathrm{Mg}, \mathrm{Fe}$ and $\mathrm{P}$ ), causing oxidative stress (Ducic and Polle, 2005; Lei et al., 2007). The threshold of $\mathrm{Mn}$ injury as well as the tolerance to an excess of this metal is highly dependent on the plant species and cultivars or genotypes within a species (Foy et al., 1988, Horst, 1988).

The purpose of this review is to illustrate the most current understanding about Mn role as an essential micronutrient and as a toxic element to higher plants, the long distance and cellular transport in plants as well as the mechanisms or strategies involved for to resist an overload of this metal. The forms and dynamics of this element in soils and the importance of the acidity for this dynamic and availability to plants are also given.

\section{MANGANESE FORMS DYNAMICS IN SOILS}

AND

Manganese biogeochemistry in soils is complex, because it is present in several oxidation states $(0$, II, III, IV, VI and VII), while in biological systems it occurs preferably as II, III and IV. Divalent manganese (Mn II) is the most soluble species of $\mathrm{Mn}$ in soil, whereas the solubility of Mn III and Mn IV are very low (Guest et al., 2002). Mn oxides can form co-precipitates with iron ( $\mathrm{Fe})$ oxides, exhibiting amphoteric behavior. In addition, Mn interacts both with cations and anions in oxidation-reduction reactions involving $\mathrm{Mn}$. These reactions are influenced by a variety of physical, chemical and microbiological processes (Bradl, 2004).

Both $\mathrm{pH}$ and redox conditions influence $\mathrm{Mn}$ bioavailability in soils (Marschner, 1995; Porter et al., 2004). In most acid soils at low $\mathrm{pH}(<5.5)$ and an increased redox potential of $\mathrm{Mn}$, oxides can be easily reduced in the soil exchange sites (Kogelmann and Sharpe, 2006), increasing the concentration of soluble $\mathrm{Mn}^{2+}$ (Watmough et al., 2007), which is the predominant $\mathrm{Mn}$ form in the soil solution (Adriano, 2001) and the most available Mn form for plants (Marschner, 1995). At higher soil $\mathrm{pH}$ (up to $\mathrm{pH} \mathrm{8)}$, chemical $\mathrm{Mn}^{2+}$ auto-oxidation is favored over $\mathrm{MnO}_{2}, \mathrm{Mn}_{2} \mathrm{O}_{3}, \mathrm{Mn}_{3} \mathrm{O}_{4}$ and even $\mathrm{Mn}_{2} \mathrm{O}_{7}$, which are not normally available to plants (Ducic and Polle, 2005; Humpries et al., 2007; Gherardi and Rengel, 2004). Furthermore, high pH allows $\mathrm{Mn}$ adsorption into soil particles, decreasing their availability (Fageria et al., 2002). Nevertheless, some reports have suggested that an excess of available $\mathrm{Mn}$ is produced under reduced soil conditions, even at high soil $\mathrm{pH}$ values (Hue, 1988). A reducing environment can be produced when there is an excess of water, poor drainage or applications of organic material (Hue, 1988; El-Jaoual and Cox, 1998). Different organic molecules can dissolve solid Mn oxides through transfer of electrons, transforming them into an available $\mathrm{Mn}$ form for plants (Laha and Luthy, 1990). Soil acidification is also accentuated by abundant pluviometry during winter, causing the main cations to leak from the soil (Mora et al., 2006). On the other hand, lime application is a key factor in decreasing soluble $\mathrm{Mn}$ in acid soils with a high $\mathrm{Mn}$ content, given that it can increase soil pH (Hue and Mai, 2002). 
The total Mn content in soils is variable. Sparks (1995) reported small amounts of $\mathrm{Mn}$ in soils, fluctuating from 20 to 10,000 $\mathrm{mg} \mathrm{kg}^{-1}$ soil, whereas other authors have registered total $\mathrm{Mn}$ contents between 450 and $\sim 4,000 \mathrm{mg} \mathrm{Mn} \mathrm{kg}{ }^{-1}$ soil (Adriano, 2001). In addition, the total Mn soil content was from 15 to $17 \mathrm{mg} \mathrm{kg}^{-1}$ in acid soils without liming ( $\mathrm{pH}$ about 4.4) (Hue and Mai, 2002). In liming acid soils, the interchangeable $\mathrm{Mn}$ concentration varied from 14 to $96 \mathrm{mg} \mathrm{kg}^{-1}$ soil in one year, with higher concentrations under high moisture and temperature conditions (Conyers et al., 1997). In Chilean volcanic soils, so-called Andisols, Mn concentrations fluctuate between 4.5 and $80 \mathrm{mg} \mathrm{kg}^{-1}$ depending on the agronomic management. Moreover, the Mn amount is higher in pasture soils (up to $400 \mathrm{mg}$ $\mathrm{kg}^{-1}$ ) mainly in winter (Data from Laboratorio de Análisis de Suelo y Planta, Universidad de La Frontera, Temuco, Chile).

Environmental conditions also affect $\mathrm{Mn}$ soil contents. The highest concentrations of soluble and exchangeable Mn are found after hot, dry summers and under warm waterlogged conditions in acid soils. This is probably due to the inhibition of Mn-oxidizing organisms, thereby allowing the chemical reduction of $\mathrm{Mn}$ oxides in these soils (Sparrow and Uren, 1987; Conyers et al., 1997).

\section{Manganese dynamics in the rhizosphere}

Rhizosphere, which is the narrow zone of soil immediately surrounding the root system, is of great importance for mineral plant nutrition. In this zone, both the mobilization and immobilization of nutrients occur (Marschner, 1995). As shown in Figure 1, a mobilization of $\mathrm{Mn}^{2+}$ is produced by the rhizosphere acidification due to the release of $\mathrm{H}^{+}$or low molecular weight organic acids
(LMWOA) from plants (Rengel and Marschner, 2005). Organic acids released in anion forms from roots can chelate $\mathrm{Mn}^{2+}$ released from the $\mathrm{MnOx}(\mathrm{Mn}$ oxides) (Ryan et al., 2001). Neumann and Römheld (2001) reported that mobilization of micronutrients (including $\mathrm{Mn}$ ) into the rhizosphere is due mainly by its acidification and complexation with the organic acids (citrate) in various plant species. It has been reported that organic amendments (chip compost and pine bark) applied to melon plants released organic compounds such as arabinose and malic acid that can dissolve $\mathrm{MnO}_{\mathrm{x}}$ (Tsuji et al., 2006). Soil microorganisms can also help Mn mobilization and immobilization, depending on soil conditions (Marschner, 1995). In aerated soils, microorganisms may mobilize $\mathrm{Mn}$ through $\mathrm{MnOx}$ reduction favored by $\mathrm{H}^{+}$ root excretion. In contrast, Mn-oxidizing bacteria can decrease $\mathrm{Mn}$ availability in aerated and calcareous soils or in poorly aerated and/or submerged soils. Another key factor in the Mn dynamics in soil is organic matter $(\mathrm{OM})$. Given that $\mathrm{OM}$ is negatively charged, it has a great $\mathrm{Mn}$ adsorption capacity, forming $\mathrm{Mn}$ complexes which decrease the amount of exchangeable Mn. However, the Mn adsorbed by $\mathrm{OM}$ can be exchanged by the $\mathrm{H}^{+}$released from the roots (Bradl, 2004).

\section{MANGANESE TRANSPORT \\ ACCUMULATION IN PLANTS}

AND

As mentioned above, reduced $\mathrm{Mn}\left(\mathrm{Mn}^{2+}\right)$ form is the only available metal form for plants. It can be taken up via an active transport system in epidermal root cells and transported as divalent cation $\mathrm{Mn}^{2+}$ into the plants (Marschner, 1995; Gherardi and Rengel, 2003; Pittman, 2005). Manganese uptake by roots is characterized as a biphasic process. The initial and rapid uptake phase is reversible and non-metabolic, with $\mathrm{Mn}^{2+}$ and $\mathrm{Ca}^{2+}$ or 


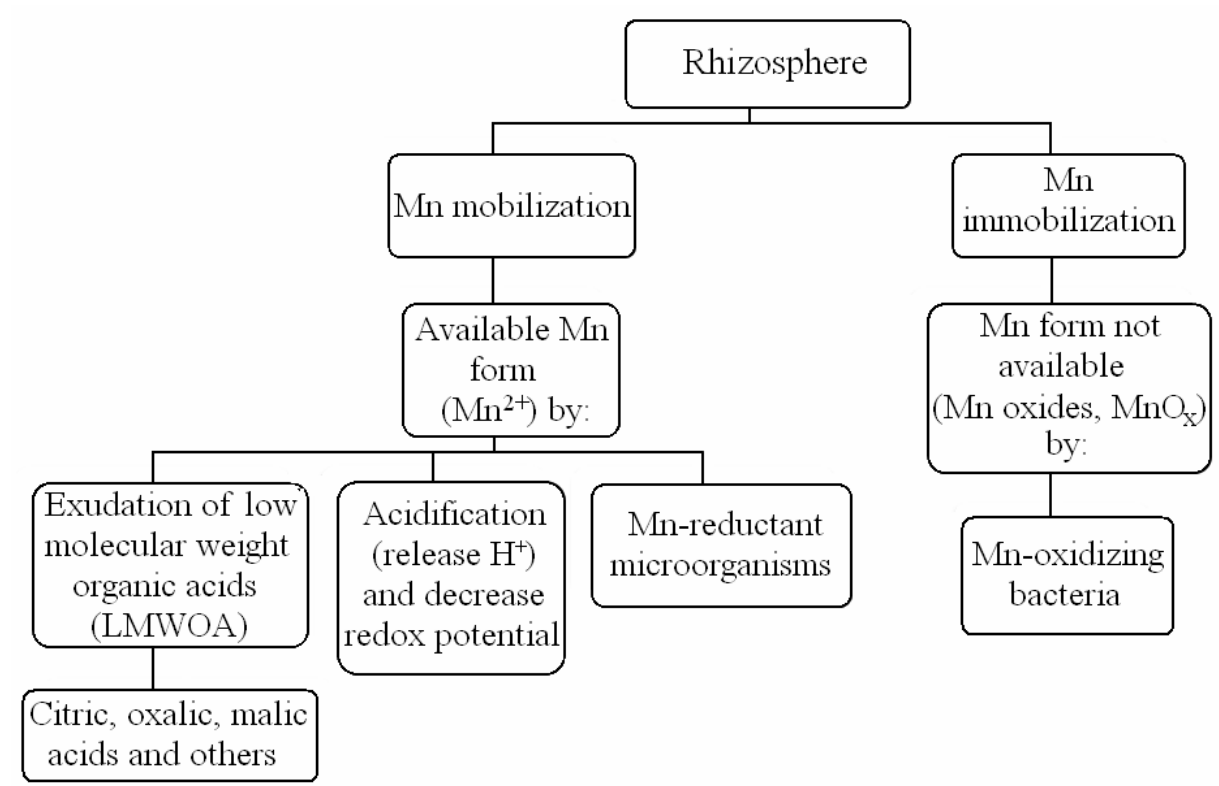

Figure 1. The role of soil rhizosphere in the mobilization and immobilization of Mn in soils.

other cations being freely exchanged in the rhizosphere. In this phase, $\mathrm{Mn}^{2+}$ appears to be adsorbed by the negatively charged cell wall constituents of the rootcell apoplastic spaces (Humphries et al., 2007; Clarkson, 1988). The second phase is slow, with $\mathrm{Mn}^{2+}$ being less readily exchanged. Its uptake into the symplast is dependent on plant metabolism (Maas and Moore, 1968), although the exact mechanisms are not clear (Humphries et al., 2007). It has been shown that in transgenic tobacco transformed with a tomato root protein with a metal binding side at its N-terminus (LeGlp1), Mn binds to this protein. This strongly suggests the involvement of LeGlp1 in Mn uptake from the soil (Takahashi and Sugiura, 2001). Kinetic measurements have demonstrated 100 to 1,000 times higher rates of $\mathrm{Mn}$ transport than the estimated plant requirement for this element (Clarkson, 1988). These transport rates are explained by the high capacity of ion carriers and channels in the $\mathrm{Mn}$ ion transportation through the plasma membrane at a speed of several hundred to several million ions per second per protein molecule (Humphries et al., 2007). According to these authors, Mn distribution from root cells within the whole plant involves primary transport in the xylem, transference from the xylem to the phloem and re-translocation into the phloem. Xylem transport from roots to the above-ground parts of plants is performed by the transpiration stream, whereas phloem transport is more selective, taking place from sources to sinks (Marschner, 1995). Nonetheless, a low mobility in phloem has been reported for $\mathrm{Mn}$, and its redistribution may depend on the plant species and stages of development (Herren and Feller, 1994). In fact, it has been reported that $\mathrm{Mn}$ transport from roots to grains is frequently insufficient at 
a mature stage of wheat. The relatively poor Mn mobility in the phloem emphasizes the importance of xylem in the transport of this element, even in wheat grain discharge (Rengel, 2001).

Manganese generally tends to accumulate predominantly in the plant shoots than in the roots, as demonstrated in Mn labeling experiments with ${ }^{54} \mathrm{Mn}$ at an early stage of wheat (Triticum aestivum cv. Arina) development, where a fast $\mathrm{Mn}$ transport from roots to shoots was visualized in the xylem and was essentially immobile in the phloem (Page and Feller, 2005). Similar effects on Mn translocation have been shown by the same technique in young (28 days) white lupine plants (Lupinus albus) (Page et al., 2006). Nevertheless, Mn was present in a large amount in the root system, hypocotyls and stem in older lupine plants, immediately after the labeling phase (day 0). Seven days later (day 7) almost all ${ }^{54} \mathrm{Mn}$ had moved to the youngest fully expanded leaves and only a small fraction to the other leaves. $\mathrm{Mn}$ accumulation was observed in the periphery of the oldest leaves. These authors reported that $\mathrm{Mn}$ was rapidly released from the roots into the xylem, reaching photosynthetically active leaves via the transpiration stream. Furthermore, the low mobility of this element via phloem in the shoot may be due to a restricted loading of soluble $\mathrm{Mn}$ into the phloem or by insolubilization in the leaves, although the issue remains to be clarified (Page et al., 2006). Page and Feller (2005) emphasized that little is known about the mechanisms involved in the loading of $\mathrm{Mn}$ into the phloem and the chemical transport forms.

In addition to the long distance transport of $\mathrm{Mn}$, short distance transport mechanisms are important for the translocation of this metal into the cell and cell organelles. These mechanisms involve Mn translocation throughout the plasma membrane and the biomembranes of organelles (Ducic and Polle, 2005; Pittman, 2005). Possible mechanisms of homeostasis and Mn transport, based on studies performed in yeast (Saccharomyces cerevisiae) cells and in Arabidopsis thaliana plants, have been discussed (Delhaize et al., 2007; Reddi et al., 2009). They pointed out that transport proteins play an important role for the maintenance of adequate $\mathrm{Mn}$ concentrations in the cytoplasm. Moreover, a variety of metal transporter family proteins with a broad-specificity such as $\mathrm{Fe}^{2+}$ and $\mathrm{Ca}^{2+}$ transporters have also the ability to transport $\mathrm{Mn}$ into the plant cells (Pittman, 2005). Migocka and Klobus (2007) demonstrated the activation of an antiport system in Cucumis sativus with different affinities for $\mathrm{Pb}, \mathrm{Mn}, \mathrm{Ni}$ and $\mathrm{Cd}$ in the root plasma membrane. This antiport system participates as part of the general defense mechanism activated under heavy metal stress. Using tonoplast-enriched vesicles, Shigaki et al., (2003) suggested that a $\mathrm{Cd} / \mathrm{H}$ antiporter might also be involved in $\mathrm{Mn}$ accumulation in vacuoles.

In Table 1 we have summarized some of the metal transporter proteins, their families, cellular localization and the transported metals. Transporter proteins are described according to their localization. In the plasma membrane, four $\mathrm{Mn}^{2+}$ uptake transporters are identified: AtIRT1, Nramp, AtYSL (Ducic and Polle, 2005; Pittman, 2005) and PHO84 (Ducic and Polle, 2005). IRT1 can transport Mn when expressed in yeast (Korshunova et al., 1999). Nramp is also considered a metal transporter protein that can transport Mn away from other cations. This protein may be localized in the tonoplast rather than in the plasma membranes (Thomine et al., 2003). AtYSL belongs to the yellow stripe-like (YSL) proteins, also involved in metal-complex transport in the plasma 
membrane (Roberts et al., 2004). This complex can be formed by nicotianamine (NA), which is a strong chelator of metals including $\mathrm{Mn}^{2+}$ (Pittman, 2005). PHO84 is a transporter protein identified in $S$. cerevisiae and it has a high-affinity phosphate uptake (Mitsukawa et al., 1997). Luk et al. (2003) reported a new form in $\mathrm{Mn}$ transport as $\mathrm{MnHPO}_{4}$. However, there is no evidence for $\mathrm{Mn}^{2+}$ or $\mathrm{MnHPO}_{4}$ accumulation by a plant phosphate transporter (Pittman, 2005).

Some transport proteins have been related to $\mathrm{Mn}^{2+}$ transport and accumulation into the intracellular compartments, such as the vacuole. It has been suggested that a metal transporter (specifically antiporter CAX2, calcium exchanger 2) originally identified as a $\mathrm{Ca}^{2+}$ transporter (which can also transport $\mathrm{Cd}^{2+}$ ) located in the cytosol. It has also the ability to transport $\mathrm{Mn}$ to the vacuole in tobacco plants (Nicotiana tabacum) and yeast (Hirschi et al., 2000; Pittman, 2005) (Table 1). ATP-binding cassette (ABC) protein transporters are considered to be involved in detoxification processes (Martinoia et al., 2002). Studies on cyanobacteria also suggested the putative role of these proteins in $\mathrm{Mn}^{2+}$ transport (Bartsevich and Pakrasi, 1996).

Another protein, considered indirectly as a metal transport protein is the ShMTP1, which is able to sequester metal ions within cells or efflux them out of the cells (Delhaize et al., 2003). Therefore, these authors considered it a metaltolerant protein. Ducic and Polle, (2005) and Pittman (2005) highlighted that, despite the available information about $\mathrm{Mn}$ transport across membranes in plant cells, the $\mathrm{Mn}$ transport and efflux strategies into the mitochondria, chloroplasts and Golgi are not completely understood. Nonetheless, Mills et al. (2008) have recently identified a CaATPase that also transports $\mathrm{Mn}^{2+}$ into Golgi apparatus (Table 1).

\section{MANGANESE AS AN ESSENTIAL ELEMENT IN PLANT METABOLISM}

The main Mn role in photosynthesis is its involvement in the water-splitting system of photosystem II (PSII), which provides electrons necessary for photosynthetic electron transport. In water photolysis, a group of four $\mathrm{Mn}$ atoms (Mn cluster) is associated with the oxygen evolving complex (OEC) bound to the reaction center protein (D1) of PSII (Goussias et al., 2002). The Mn cluster in PSII accumulates four positive charges, which oxidize two water molecules, releasing one $\mathrm{O}_{2}$ molecule and four protons. Therefore, this metal cluster is considered a catalyst compound of water oxidation (Zouni et al., 2001), where $\mathrm{Mn}$ ions are close to a redox-active tyrosine residue ( $\mathrm{Z}$ and $\mathrm{D}$ ) (Goussias et al., 2002).

Manganese also plays a role in ATP synthesis (Pfeffer et al., 1986), in RuBP carboxylase reactions (Houtz et al., 1988) and the biosynthesis of fatty acids, acyl lipids and proteins (Ness and Woolhouse, 1980). In addition, Mn plays a primary role in the activation and as cofactor of various enzymes in plants $(\sim 35)$ (Burnell, 1988), such as: Mn-superoxide dismutase, Mn-catalase, pyruvate carboxylase and phospho-enolpyruvate carboxykinase (Ducic and Polle, 2005). Manganese is also essential for the biosynthesis of chlorophyll (through the activation of specific enzymes), aromatic amino acids (tyrosine), secondary products, like lignin and flavonoids (Lidon et al., 2004). It also participates in the biosynthetic pathway of isoprenoids (Lidon et al., 2004) and assimilation of nitrate (Ducic and Polle, 2005). Hence, $\mathrm{Mn}$ is involved in metabolic processes such as respiration, photosynthesis, synthesis of aminoacids and hormone activation (indol acetic acid, IAA) throughout the IAA-oxidases (Burnell, 1988). 
Table 1. Some transporter proteins implicated in $\mathrm{Mn}^{2+}$ and other cations transport and their cellular localization. (Summarized from Ducic and Polle, 2005; Pittman, 2005 and Mills et al., 2008). Abbreviations as follows: At= Arabidopsis thaliana; Sh= Stylosanthes hamata).

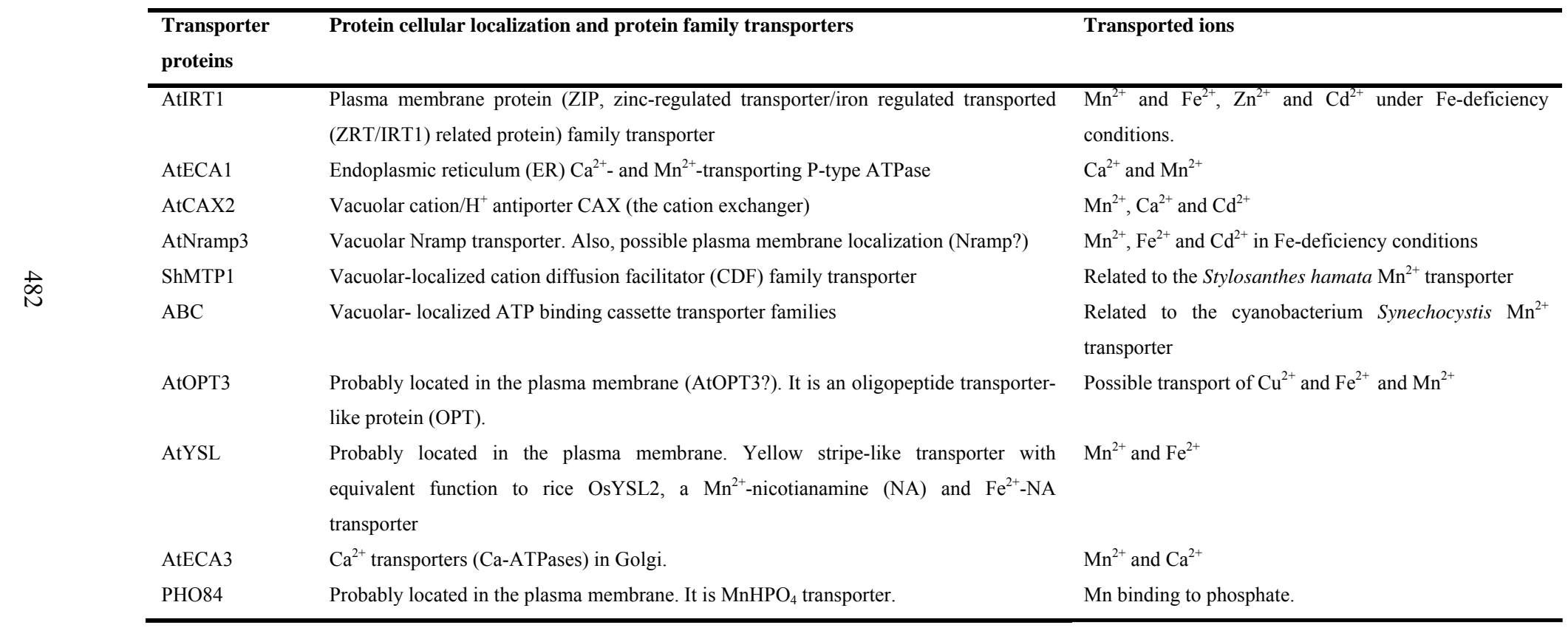


As a cofactor of superoxide dismutase (SOD), manganese participates in the plant's defense against oxidative stress, produced by elevated levels of activated forms of oxygen and free radicals (reactive oxygen species, ROS), which are harmful to plants. It has been proposed that Mn can act as a scavenger of superoxide $\left(\mathrm{O}_{2}{ }^{-}\right)$and hydrogen peroxide $\left(\mathrm{H}_{2} \mathrm{O}_{2}\right)$. However, this mechanism is still unclear (Ducic and Polle, 2005).

Manganese SOD (MnSOD) belongs to the group of metal-containing SOD enzymes which are classified according to their metal cofactor: iron SOD (Fe-SOD), localized in the chloroplast; copper-zinc SOD $(\mathrm{Cu} / \mathrm{Zn}-\mathrm{SOD})$, located in the chloroplast, cytosol, and possibly in the extracellular space. Manganese SOD is found mainly in mitochondria (Clemens et al., 2002) and peroxisomes (Alscher et al., 2002). MnSOD may play an important role in the adaptive responses of plant cells under environmental stresses such as salt stress, enhancing their tolerance. This tolerance has been demonstrated in transgenic plants of Arabidopsis, where Mn-SOD was overexpressed (Wang et al., 2004). Similarly, in tomato transgenic plants which overexpressed MnSOD, an improvement in tolerance to $\mathrm{NaCl}$ stress in seedlings was concomitant with an improvement in seed germination and root development (Wang et al., 2007).

\section{MANGANESE PHYTOTOXICITY AND INJURY SYMPTOMS}

As an essential micronutrient, low $\mathrm{Mn}$ levels are absolutely necessary for normal nutrition and development of plants. Normal Mn contents of leaves differ greatly between species (30-500 $\mathrm{mg} \mathrm{kg}^{-1}$ $\mathrm{Mn}$ dry mass, Clarkson, 1988). Nonetheless, when it is present in excessive amounts, it is extremely toxic to plant cells (Migocka and Klobus, 2007). The injury extent of $\mathrm{Mn}$ toxicity is approximately proportionate to the concentration of accumulated Mn excess. However, there is considerable inter- and intra- specific variation among Mn levels that induce toxicity as well as the symptoms of this toxicity in plant species (Foy et al., 1988).

In addition to a decrease in growth rate, symptoms of $\mathrm{Mn}$ toxicity such as chlorosis in leaves (intervenial and marginal) and necrotic leaf spots are very common and have been reported in the whole plants of canola (Moroni et al., 2003), clover (Rosas et al., 2007), ryegrass (Mora et al., 2009) as well as in leaves of barley and cowpea (Demirevska-Kepova et al., 2004; Führs et al., 2008) (Table 2). Necrotic brown spots and chlorotic leaves are frequently reliable indicators of the severity of $\mathrm{Mn}$ toxicity in plants (Wissemeier and Horst, 1991). The intervenial chlorosis due to $\mathrm{Mn}$ toxicity can have an appearance similar to that observed under $\mathrm{Fe}$ deficiency (Sarkar et al., 2004). Moreover, the Mn toxicity is intensified when other available elements such as $\mathrm{Ca}$, $\mathrm{Mg}, \mathrm{K}, \mathrm{Fe}$ and $\mathrm{Si}$ are in a low quantity (Abou et al., 2002). However, a decrease in productivity by Mn toxicity without the appearance of leaf visual symptoms is sometimes observed (Miner and Sims, 1983). It is important to know that all these symptoms induced by $\mathrm{Mn}$ toxicity are preceded by an alteration of the photosynthetic apparatus and the photosynthetic performance of plants.

Other studies have shown that in rice (Oryza sativa cv. Safari) exposed to $\mathrm{Mn}$ excess in a nutrient solution, Mn was predominantly accumulated in leaves compared with roots (Lidon, 2001), whereas in Sinapis alba Mn mostly accumulated in the shoots (Farasova and Beinrohr, 1998). 
Table 2. Symptoms of Mn toxicity and Mn concentrations in organs of some plant species subjected to toxic Mn concentrations according references from the last decade (earlier references in the text). Mn treatments were performed in nutrient solutions with $\mathrm{MnCl}_{2}$ or $\mathrm{MnSO}_{4}$.

\begin{tabular}{|c|c|c|c|c|}
\hline Species & Mn treatment & $\begin{array}{l}\text { Mn concentrations in } \\
\text { different plant organs }\end{array}$ & Symptoms of Mn toxicity & References \\
\hline Rice (Oryza sativa L.) & $583 \mu \mathrm{M}$ & Shoots: $2020 \mu \mathrm{g} \mathrm{g}^{-1} \mathrm{dw}$ & Decrease of shoot growth rate. & $\begin{array}{l}\text { Lidon and Texeira } \\
(2000 \mathrm{a})\end{array}$ \\
\hline Barley (Hordeum vulgare L.) & $\begin{array}{l}1830 \mu \mathrm{M} \\
18300 \mu \mathrm{M}\end{array}$ & $\begin{array}{l}\text { Leaves: } 656 \mathrm{mg} \mathrm{g}^{-1} \mathrm{dw} \\
\text { Leaves: } 1615 \mathrm{mg} \mathrm{g}^{-1} \mathrm{dw}\end{array}$ & Dark-brown necrotic spots, individually or in groups. & $\begin{array}{l}\text { Demirevska-Kepova et } \\
\text { al. (2004) }\end{array}$ \\
\hline Ryegrass (Lolium perenne L.) & $355 \mu \mathrm{M}$ & $\begin{array}{l}\text { Shoot: } 2357 \mathrm{mg} \mathrm{kg}^{-1} \\
\text { Roots: } 2408 \mathrm{mg} \mathrm{kg}^{-1}\end{array}$ & $\begin{array}{l}\text { Chlorotic leaves. } \\
\text { Decrease of dry weight in roots. }\end{array}$ & Rosas et al. (2007) \\
\hline Ryegrass (L. perenne L.) & $150 \mu \mathrm{M}$ & $\begin{array}{l}\text { Shoot: } 902 \mathrm{mg} \mathrm{kg}^{-1} \\
\text { Roots: } 1342 \mathrm{mg} \mathrm{kg}^{-1}\end{array}$ & $\begin{array}{l}\text { Dry weight reduction. } \\
\text { Dry weight reduction. }\end{array}$ & Mora et al. (2009) \\
\hline Clover (Trifolium repens L.) & $355 \mu \mathrm{M}$ & $\begin{array}{l}\text { Shoot: } 2050 \mathrm{mg} \mathrm{kg}^{-1} \\
\text { Root: } 7481 \mathrm{mg} \mathrm{kg}^{-1}\end{array}$ & $\begin{array}{l}\text { Reddish borders on leaves. } \\
\text { Decrease of dry weight. }\end{array}$ & Rosas et al. (2007) \\
\hline Soybean (Glycine max L.) & $200 \mu \mathrm{M}$ & $\begin{array}{l}\text { Leaves: } 806 \mathrm{mg} \mathrm{kg}^{-1} \\
\text { Roots: } 502 \mathrm{mg} \mathrm{kg}^{-1}\end{array}$ & $\begin{array}{l}\text { Chlorotic leaves. } \\
\text { No visual symptoms, increase in root diameter. }\end{array}$ & Lavres Jr et al. (2009) \\
\hline Cowpea (Vigna unguiculata L.) & $50 \mu \mathrm{M}$ & Leaves: $\sim 25 \mu \mathrm{mol} \mathrm{g}^{-1} \mathrm{dw}$ & Brown spots on leaves. & $\begin{array}{l}\text { Führs et al. (2008, } \\
2009)\end{array}$ \\
\hline $\begin{array}{l}\text { Canola (Brassica napus L.) } \\
\text { Juncus effuses L. (wetland plant) }\end{array}$ & $\begin{array}{l}200 \mu \mathrm{M} \\
500 \mu \mathrm{M}\end{array}$ & $\begin{array}{l}\text { Shoot: } \sim 3500 \mu \mathrm{g} \mathrm{g}^{-1} \mathrm{dw} \\
176 \mathrm{mg} \mathrm{kg}^{-1}\end{array}$ & $\begin{array}{l}\text { Necrotic leaf spots, chlorosis in leaf margin. } \\
\text { Reduction in plant dry biomass and height, no } \\
\text { phytotoxic visual symptoms. }\end{array}$ & $\begin{array}{l}\text { Moroni et al. (2003) } \\
\text { Najeeb et al. (2009) }\end{array}$ \\
\hline Populus cathayana & $1000 \mu \mathrm{M}$ & Leaves: $713 \mathrm{mg} \mathrm{kg}^{-1} \mathrm{dw}$ & $\begin{array}{l}\text { Decrease in shoot height, total biomass, and total leaf } \\
\text { area. }\end{array}$ & Lei et al. (2007) \\
\hline
\end{tabular}


Despite the importance of Mn excess in the photosynthetic performance of plants, only a few studies about this issue are available. A reduction in photosynthesis, in chlorophyll $a$ and $b$ contents and their biosynthesis, as well as a reduction in carotenoids is frequently found in plants and also in algae under $\mathrm{Mn}$ excess (Macfie and Taylor, 1992; Hauck et al., 2003). In rice cultivated at different $\mathrm{Mn}$ concentrations (from 2.3 to $583 \mu \mathrm{M}$ ), a significant decrease in chlorophyll $a$ content has been reported at the highest $\mathrm{Mn}$ concentration (Lidon and Teixeira, 2000a). Nable et al. (1988) reported an early inhibition of photosynthesis concomitant with a high Mn accumulation in the leaves in Nicotiana tabacum cultivated in nutrient solutions with a Mn excess $(1,000 \mu \mathrm{M})$. The authors concluded that the inhibition of photosynthesis is an early indicator for Mn toxicity in tobacco leaves. Lidon et al., (2004) also observed a decline in net photosynthesis ( $\mu \mathrm{mol} \quad \mathrm{CO}_{2} \mathrm{~m}^{-2} \mathrm{~s}^{-1}$ ) and photosynthetic capacity $\left(\mu \mathrm{mol} \mathrm{O} \mathrm{O}^{-2} \mathrm{~s}^{-1}\right)$ in rice plants subjected to 9.1 and 36.4 $\mu \mathrm{M}$ Mn treatment, respectively, with no changes in the levels of the ratio between variable $(\mathrm{Fv})$ and maximum $(\mathrm{Fm})$ chlorophyll fluorescence (Fv/Fm). However, an increase in the photochemical quenching and the quantum yield of non-cyclic electron transport was found up to $36.4 \mu \mathrm{M} \mathrm{Mn}$. Since $\mathrm{Mn}$ is accumulated in thylakoids, this element may interfere with thylakoid stacking, decreasing net photosynthesis (Lidon and Teixeira, 2000a).

Similarly to $\mathrm{Mn}$ toxicity, Mn deficiency also depressed leaf photosynthetic capacity in plants of Carya illinoinensis, primarily by reducing the number of PSII units per unit leaf area, but these PSII units maintained abilities similar to those of the control plants (Henriques, 2003). Increased Mn concentrations $(0-1,000$ and $10,000 \mu \mathrm{M}$
Mn) in wheat plants inhibited the biosynthesis of chlorophyll and carotenoids, inducing a decrease in photosynthetic electron transport rates and therefore a decrease in the rate of photosynthesis (Macfie and Taylor, 1992). Higher Mn concentrations are also involved in a shortening of root and shoot and in a decreased chlorophyll concentration in the $\mathrm{Mn}$ accumulator plant, Alyssum murale (Abou et al., 2002). Recently, Amao and Ohashi (2008) suggested that high Mn amounts in spinach leaves inhibited the activity of oxygen evolved complex of PSII.

\section{Manganese toxicity and oxidative stress}

Mn toxicity can also trigger oxidative stress in plant cells (Demirevska-Kepova et al., 2004). As a toxic metal, Mn can cause metabolic alterations and macromolecular damage that disrupt the cell homeostasis (Hegedüs et al., 2001; Polle, 2001). According to Lynch and St. Clair (2004), Mn toxicity in plants generates reactive oxygen species (ROS), mainly $\mathrm{OH}$, the most reactive oxidant and harmful species in cells (Lidon and Henriques, 1993). With respect to the oxidative stress responses to $\mathrm{Mn}$ excess, Lidon and Teixeira (2000b) reported that at the first growth stages of rice, two kinetic phases can be distinguished: in the first one, there is an increase in $\mathrm{Mn}$ accumulation in the thylakoid lamellae (McCain and Markley, 1989), which inhibits electron leakage from the Hill and Mehler reactions, limiting ROS formation. In the second kinetic phase, higher Mn amounts inhibit the non-cyclic photophosphorylation process, promoting an increase in ROS production that parallels an injury increase in the thylakoid peroxidase system (Lidon and Teixeira, 2000b). These authors concluded that $\mathrm{Mn}$ excess increases the disorganization in chloroplast lamellae, 
but elevated activity of superoxide dismutase (SOD) still limits cell damage.

It has also been reported that in Cucumis sativus plants both $\mathrm{Mn}$ excess and optimum light intensity determine an enhancement in oxidative stress by increased $\mathrm{Mn}$ content in the tissues concomitant with an inhibition of plant growth (Shi et al., 2006). Investigations performed by González et al., (1998) showed that lipid peroxidation was not induced by Mn-toxicity stress in the mature leaves of Phaseolus vulgaris, although other studies have shown that lipid peroxidation occurred in isolated chloroplast of wheat (Panda et al., 1986). However, González et al. (1998) mentioned that this damage process could be related to the development stage of leaves, with the damage being more intense in immature than in mature leaves.

The geographical origin of the species and climatic conditions also affect the degree of Mn toxicity in plant species or populations as shown in two populations of Populus cathayana, coming from a wet and dry climate cultivated in an acid solution with increasing $\mathrm{Mn}$ concentrations (Lei et al., 2007). The results showed that the wet climate population accumulated more $\mathrm{Mn}$ in plant tissues especially in leaves, decreasing their growth, chlorophyll contents, and activities of antioxidant enzymes than the dry climate population.

\section{TOLERANCE MECHANISMS MANGANESE TOXICITY}

The ability of plant for to grow and survive in a metal-contaminated environment, commonly called resistance, can be achieved through different mechanisms: avoidance and/or tolerance. The former involves a protective role that prevents the metal ions from entering the cytoplasm of plant cells (Blamey et al.,
1986; Marschner, 1991). The latter strategy (tolerance) implies a detoxification of metal ions after they have crossed the plasma cell membrane or internal organelle biomembranes (Macfie et al., 1994). However, as shown in the following paragraphs, the differentiation of these mechanisms in the pertinent literature is very confusing.

The sequestering of $\mathrm{Mn}$ in the apoplast is considered an avoidance mechanism. However, some researchers have included this feature as a tolerance mechanism. For example, Horst et al., (1999) suggested that tolerance to $\mathrm{Mn}$ excess in Vigna unguiculata is performed by the reduction of $\mathrm{Mn}^{2+}$ activity in the apoplast throughout complexation by organic acids. In this species, symptoms such as brown leaf cell spots are also identified as oxidized $\mathrm{Mn}$, and phenolic compounds present in the cell walls are considered a $\mathrm{Mn}$ tolerance mechanism (Wissemeier and Horst, 1992). On the other hand, the $\mathrm{Mn}^{2+}$ oxidation by peroxidases in the cell walls of roots is considered by Marschner (1991) as an avoidance mechanism, although the existence of such a mechanism was not considered in the study of Horiguchi (1987). In this study, it is suggested that oxidized Mn deposition in plant tissues corresponds to a tolerance mechanism to Mn toxicity, with Cucumis sativus being more tolerant to high $\mathrm{Mn}$ deposition in tissues than melon (Cucumis melo). Blamey et al., (1986) reported the accumulation and secretion of $\mathrm{Mn}^{2+}$ in and around the trichomes of sunflower plants (Helianthus annuus) as a $\mathrm{Mn}$ tolerance mechanism. Another strategy that plants use to prevent the toxic effects of heavy metals as well as of Mn can be the efflux from the cell. In this process, the $\mathrm{Mn}$ cell is delivered into the Golgi apparatus and finally exported from the cell via secretory pathway vesicles that carry the metal to the cell surface (Ducic and Polle, 2005). 
Summarizing the available literature regarding tolerance mechanisms to $\mathrm{Mn}$, it appears that the main Mn tolerance mechanism is the sequestration by organic compounds in metabolically less active cells or organelles. The vacuole is considered the biggest and most important compartment, because it can store many toxic compounds (Pittman, 2005). Hence, an increase in phenolic compounds was found in the hydrophyte (Trapa natans) leaves exposed to high Mn levels (130 $\mu \mathrm{M})$ (Baldisserotto et al., 2004). These compounds chelate $\mathrm{Mn}$ inside the vacuole, segregating the metal ion in the protoplasm and thus reducing the damage (Davis et al., 2001). A similar key role has recently been assigned to oxalic acid in $\mathrm{Mn}$ internal sequestration by chelating specifically the Mn excess in vacuoles of Mn hyperaccumulator plants (Phytolacca americana) (Dou et al., 2008). Furthermore, it has been observed that a Mn excess can accumulate dark material in the vacuoles, probably for deposition of Mn oxides or an increase in polyphenol oxidase activity in Citrus volkameriana plants (Papadakis et al., 2007). Similarly, studies about the effect of Mn excess in varieties of the conifer Pseudotsuga menziesii showed dark deposits of Mncomplexes in plant root vacuoles, which were associated with phosphate, establishing "free" $\mathrm{Mn}^{2+}$ to form insoluble complexes, giving a greater tolerance (Ducic and Polle, 2007). Additionally, these studies showed that both, root elongation and biomass production were inhibited by $\mathrm{Mn}$ treatment above 2,500 $\mu \mathrm{M}$, mainly in $P$. menziesii var. glauca, confirming that it is a species with lower tolerance than $P$. menziesii var. viridis.

Another strategy to confer $\mathrm{Mn}$ tolerance inside plant cells is associated with several metal transporter proteins identified in the Mn transport mechanisms described in section 4. Metal transporter proteins located in the tonoplast (CAX2 in tobacco plants, ShMTP1 in Arabidopsis plants) conferred greater tolerance on elevated $\mathrm{Mn}^{2+}$ levels due to the internal sequestering of this element (Hirschi et al., 2000; Delhaize et al., 2003). Other transporter proteins (ECA1) can maintain low cytosolic Mn, since it moves into the endoplasmic reticulum (Wu et al., 2002). In this research, ECA1 was able to reduce cytosolic $\mathrm{Mn}^{2+}$, preventing an interference with the internal distribution of other ions $\left(\mathrm{Mg}^{2+}, \mathrm{Fe}^{2+}\right.$ or $\left.\mathrm{Ca}^{2+}\right)$.

Unlike other metal stresses, the accumulation of Mn excess does not have a single cell target. Depending on the plant species, different organelles can serve as stores for this accumulation (Lidon et al., 2004). Under high Mn levels apart from vacuoles, chloroplasts are important sinks of this metal in Citrus volkmeriana. This feature, together with the larger size of this organelle, is considered to be an adaptive response of this plant to Mn excess (Papadakis et al., 2007). In general, cultivated plants like rice are considered tolerant to Mn toxicity (Lidon, 2001) because their leaf tissues can accumulate from 5 to 10 times more Mn than other grasses (Foy et al., 1978). The Mn tolerance mechanism in this species included the inhibition of apoplastic influx from the cortex toward the stele and symplastic Mn assimilation in the shoot protoplast, where the chloroplast is the main target (Lidon, 2001).

The distribution of Mn excess in both roots and shoots is dependent on plant species and genotype. Early research associated $\mathrm{Mn}$ tolerance in some plants with a greater retention of Mn excess in the roots, as mentioned by Andrew and Hegarty (1969) in regard to tropical and temperate legume species. The root retention of heavy metals has been attributed to the formation of metal complexes in roots (Foy et al., 1978). Metals with high electro-negativity 
accumulate in roots in larger amounts than metals with low electro-negativity. In the latter instance, $\mathrm{Mn}$ and $\mathrm{Zn}$ metals can easily be translocated to the tops (Chino, 1981).

In proteomics studies, a comparison of Mn-sensitive and Mn-tolerant cultivars of cowpea (Vigna unguiculata.) has shown relevant features of leaf apoplast in the expression of Mn toxicity: formation of brown spots, induction of callose formation and an enhanced release of phenols and peroxidases into the apoplast (Fecht-Christoffers et al., 2003; FechtChristoffers et al., 2006). Specific proteins involved in the regulation processes, such as $\mathrm{CO}_{2}$ fixation, stabilization of the $\mathrm{Mn}$ cluster of the photosystem II, pathogenesis-response reactions and protein degradation, were affected at low or high Mn levels, mainly in the Mn-sensitive cowpea cultivar (Führs et al., 2008). Chloroplastic proteins, which are important for $\mathrm{CO}_{2}$ fixation and photosynthesis, were of lower abundance upon Mn-induced stress, suggesting the scavenging of metabolic energy for a specific stress response. Führs et al., (2008) concluded that a coordinated interplay of apoplastic and symplastic reactions seems to be important during the Mn-stress response in plants.

To alleviate metal toxicity in plants, the antioxidant systems are also considered an important tolerance mechanism. The antioxidant systems include antioxidant enzyme "scavengers" such as superoxide dismutase (SOD), catalase (CAT), peroxidases (phenol peroxidase, POX, ascorbate peroxidase, APX, guaiacol peroxidase, GPX) and the non-enzymatic antioxidant molecules: ascorbate, $\alpha$-tocopherol, carotenoids, flavonoids and glutathione (Foyer and Noctor, 2003; Apel and Hirt, 2004). These constitute other mechanisms against ROS, produced by Mn toxicity.
Higher activities of antioxidant enzymes are found in response to a Mn excess in woody plants (Lei et al., 2007), in herbs such as white clover (Trifolium repens.) and in ryegrass (Lolium perenne), which suggest a lower oxidative stress (Rosas et al., 2007; Mora et al., 2009). Another plant tolerance mechanism to metal toxicity is associated with lower metal uptake and translocation to other organs (Hall, 2002). The exudation of organic acid anions (carboxylates) to the rhizosphere may minimize the absorption by roots of such metals as aluminium and nickel (Ma et al., 2001; Yang et al., 1997). There are few reports regarding the release of organic acid anions by roots in the event of Mn toxicity (González and Lynch, 1999). Recently, Mora et al. (2009) reported that the root exudates of oxalate and citrate may decrease $\mathrm{Mn}$ availability in the rhizosphere, enhancing their $\mathrm{Mn}$ tolerance in ryegrass subjected to Mn toxicity.

Other nutrient applications can help minimize the effects of Mn toxicity. Thus, it has been reported that silica (Si) addition significantly decreases lipid peroxidation caused by an Mn excess decreasing the symptoms of $\mathrm{Mn}$ phytotoxicity and improving plant growth in some plants (Iwasaki et al., 2002; Shi et al., 2005). There is also an association between Mn toxicity and the decrease in $\mathrm{Ca}$ concentration in barley plants (Hordeum vulgare), indicating a competition and a specific interaction during the absorption and/or translocation of these elements (Alam et al., 2001). Another study, in which $\mathrm{Ca}$ is applied to reduce the $\mathrm{Mn}$ toxicity, showed that $\mathrm{Ca}$ additions inhibited $\mathrm{Mn}$ translocation from roots to shoots in barley plants, but did not affect the Mn absorption in roots (Alam et al., 2006). This suggested that $\mathrm{Ca}$ could avoid $\mathrm{Mn}$ accumulation in shoots, protecting the photosynthetic apparatus from the dangerous effect of an 
excess of Mn. In barley, Mn toxicity could also be repressed by high $\mathrm{K}$ contents, which inhibit both the absorption and the translocation of $\mathrm{Mn}$ (Alam et al., 2005).

\section{CONCLUSIONS AND PERSPECTIVES}

Manganese is considered an essential micronutrient for the metabolic process in plants. Nevertheless, both deficiency and excess alter these processes. Acid soils make excessive Mn amounts toxic for the plants. Mn toxicity is a world-wide problem in areas with acid soils. This toxicity alters physiological, biochemical and molecular processes at the cell level. It is crucial to know the limitations of these soils for the purpose of soil-plant interaction management, especially in relation to the presence and $\mathrm{Mn}$ excess. Thus, the knowledge of Mn uptake, translocation, accumulation and resistance mechanisms in crop plants under $\mathrm{Mn}$ excess and toxicity is of great importance to crop improvement.

Most molecular and physiological approaches to Mn transport inside plant cells have recently been analyzed, as these are useful tools for understanding resistance mechanisms. However, the question as to which is the best candidate gene related to $\mathrm{Mn}$ toxicity in acid soil continues to elude plant scientists due to Mn toxicity in plants being a complex trait and involving multiple physiological and biochemical mechanisms and a wide array of genes. The understanding of these mechanisms will contribute to improving the yield and quality of cultivated plants in acid soils. Future efforts for developing Mn-tolerant plants should take all these aspects into account.

\section{ACKNOWLEDGMENTS}

Financial support for this review was provided by Fondo Nacional de Desarrollo Científico y Tecnológico (FONDECYT N ${ }^{\circ} 1080372$ ) and Comisión Nacional de Investigación Científica y Tecnológica (CONICYT) Doctoral Fellowship of the Government of Chile.

\section{REFERENCES}

Abou, M., Symeonidis, L., Hatzistavrou, E., Yupsanis, T. 2002. Nucleolytic activities and appearance of a new DNase in relation to nickel and manganese accumulation in Alyssum murale. J. Plant Physiol. 159, 1087-1095.

Adriano, D.C. 2001. Trace elements in terrestrial environments. Biogeochemistry, bioavailability and risks of metals. Springer-Verlag, New York, $867 \mathrm{p}$.

Alam, S., Kamei, S., Kawai, S. 2001. Amelioration of manganese toxicity in barley with iron. J. Plant Nutr. 28, 1421-1433.

Alam, S., Akiha, F., Kamei, S., Huq, S., Kawai, S. 2005. Mechanism of potassium alleviation of manganese phytotoxicity in barley. J. Plant Nutr. 28, 889-901.

Alam, S., Kodama, R., Akiha, F., Kamei, S., Kawai, S. 2006. Alleviation of manganese phytotoxicity in barley with calcium. J. Plant Nutr. 29, 59-74.

Alscher, R., Erturk, N., Heath, L. 2002. Role of superoxide dismutase (SODs) in controlling oxidative stress in plants. J. Exp. Bot. 53, 13311341

Andrew, C.S., Hegarty, M.P. 1969. Comparative responses to manganese excess of eight tropical and four temperate pasture legume species. Aust. J. Agric. Res. 20, 687-696.

Amao, Y., Ohashi, A. 2008. Effect of Mn ion on the visible light induced water oxidation activity of photosynthetic organ grana from spinach. Catal. Commun. 10, 217-220. 
Apel, K., Hirt, H. 2004. Reactive oxygen species: Metabolism, oxidative stress, and signal transduction. Annu. Rev. Plant Biol. 55, 373-379.

Baldisserotto, C., Ferroni, L., Medici, V., Pagnoni, A., Pellizzari, M., Fasulo, M.P., Fagioli, F., Bonora, A., Pancaldi, S. 2004. Specific intra-tissue responses to manganese in the floating lamina of Trapa natans L. Plant Biol. 6, 578-589.

Bartsevich, V., Pakrasi, H.B. 1996. Manganese transport in the cyanobacterium Synechocystis sp PCC 6803. J. Biol. Chem. 271, 26057-26061.

Blamey, F., Joyce, D., Edwards, D., Asher, C. 1986. Role of trichomes in sunflower tolerance to manganese toxicity. Plant Soil. 91, 171-180.

Bradl, H. 2004. Adsorption of heavy metal ions on soils and soils constituents. J. Colloid. Interf. Sci. 277, 1-18

Buchanan, B., Grusen, W., Jones, R. 2000. Biochemistry and molecular biology of plants. American Society. of Plant Physiologists Maryland. $1367 \mathrm{p}$.

Burnell, J. 1988. The biochemistry of manganese in plants. In: R.D. Graham, R.J. Hannam, N.J. Uren. (eds). Manganese in Soil and Plants. Kluwer Academic Publishers, Dordrecht, The Netherlands, pp. 125-137.

Chino, M. 1981. Metal stress in rice plants. In: K. Kitagisi, I. Yamane (eds). Heavy metal pollution in soils of Japan. Japan Scientific Societies Press, Tokyo, pp. 65-80.

Clarkson, D.T. 1988. The uptake and translocation of manganese by plant roots. In: R.D. Graham, R.J. Hannam, N.J. Uren. (eds). Manganese in Soil and Plants. Kluwer Academic Publishers, Dordrecht, The Netherlands, pp. 101111.

Clemens, K.L., Force, D.A., Britt, R.D. 2002. Acetate binding at the photosystem II oxygen evolving complex: an S2-State multiline signal ESEEM study. J. Am. Chem. Soc. 124, 1092110933.

Conyers, M., Uren, N., Helyar, K., Poile, G., Cullis, B. 1997. Temporal variation in soil acidity. Aust. J. Soil Res. 35, 1115-1129.

Davis, M.A., Pritchard, S.G., Boyd, R.S., Prior, S.A. 2001. Developmental and induced responses of nickel-based and organic defenses of the nickel-hyperaccumulating shrub, Psychotria douarrei. New. Phytol. 150, 49-58.
Delhaize, E., Kataoka, T., Hebb, D.M., White, R.G., Ryan, P.R. 2003. Genes encoding proteins of the cation diffusion facilitator family that confer manganese tolerance. Plant Cell 15, 11311142 .

Delhaize, E., Gruber, B.D., Pittman, J.K., White, R.G., Leung, H., Miao, Y., Jiang, L., Ryan, P.R., Richardson, A.E. 2007. A role for the AtMTP11 gene of Arabidopsis in manganese transport and tolerance. Plant J. 51, 198-210.

Demirevska-Kepova, K., Simova-Stoilova, L., Stoyanova, Z., Holzer, R., Feller, U. 2004. Biochemical changes in barley plants after excessive supply of copper and manganese. Environ. Exp. Bot. 52, 253-266.

Dou, C., Fu, X, Chen, X,Shi, J., Chen, Y. 2008. Accumulation and detoxification of manganese in hyperaccumulator Phytolacca americana. Plant Biol. 11, 664-670.

Ducic, T., Polle, A. 2005. Transport and detoxification of manganese and copper in plants. Braz. J. Plant Physiol. 17, 103-112.

Ducic, T., Polle, A. 2007. Manganese toxicity in two varieties of Douglas fir (Pseudotsuga menziesii var. viridis and glauca) seedlings as affected by phosphorus supply. Funct. Plant Biol. 34, 31-40.

El-Jaoual, T., Cox, D. 1998. Manganese toxicity in plants. J. Plant Nutr. 21, 353-386.

Fageria, N., Baligar, V., Clark, R. 2002. Micronutrients in crop production. Adv. Agron. 77, 185-268.

Farasova, A., Beinrohr, E. 1998. Metal-metal interaction in accumulation of $\mathrm{V}, \mathrm{Ni}, \mathrm{Mo}, \mathrm{Mn}$, and $\mathrm{Cu}$ in under and above ground parts of Sinapis alba. Chemosphere 36, 1305-1317.

Fecht-Christoffers, M., Braun, H., LemaitreGuillier, C., VanDorsselaer, A., Horst, W. 2003. Effect of manganese toxicity on the proteome of the leaf apoplast in cowpea. Plant Physiol. 133, 1935-1946.

Fecht-Christoffers, M., Führs, H., Braun, H., Horst, W. 2006. The role of hydrogen peroxideproducing and hydrogen peroxide-consuming peroxidases in the leaf apoplast of cowpea in manganese tolerance. Plant Physiol. 140, 14511463

Foy, C., Chaney, R., White, M. 1978. The physiology of metal toxicity in plants. Annu. Rev. Plant Physiol. 29, 511-566. 
Foy, C., Scott, B., Fisher, J. 1988. Genetic differences in plant tolerance to manganese toxicity. In: R.D. Graham, R.J. Hannam, N.J. Uren. (eds). Manganese in Soil and Plants. Kluwer Academic Publishers, Dordrecht, The Netherlands, pp. 293-307.

Foyer, C., Noctor, G. 2003. Redox sensing and signalling associated with reactive oxygen in chloroplasts, peroxisomes and mitochondria. Physiol. Plant. 119, 355-364.

Führs, H., Hartwig, M., Buitrago, L., Heintz, D., Van Dorsselaer, A., Braun, H., Horst, W. 2008. Early manganese-toxicity response in Vigna unguiculata L. - a proteomic and transcriptomic study. Proteomics 8, 149-159.

Führs, H., Götze, S., Specht, A., Erban, A., Gallien, S., Heintz, D., Van Dorsselaer, A., Kopka, J., Braun, H.P., Horst, W.J. 2009. Characterization of leaf apoplastic peroxidases and metabolites in Vigna unguiculata in response to toxic manganese supply and silicon. J. Exp. Bot. 60, 1663-1678.

Gherardi M., Rengel, Z. 2003. Genotypes of lucerne (Medicago sativa L.) show differential tolerance to manganese deficiency and toxicity when grown in bauxite residue sand. Plant Soil 249, 287-296.

Gherardi M., Rengel, Z. 2004. The effect of manganese supply on exudation of carboxylates by roots of lucerne (Medicago sativa). Plant Soil 260, 271-282.

González, A., Steffen, K., Lynch, J. 1998. Light and excess manganese. Plant Physiol. 118, 493504.

González, A., Lynch, J. 1999. Subcellular and tissue Mn compartmentation in bean leaf under Mn toxicity stress. Aust. J. Plant Physiol. 26, 811-822.

Goussias, C., Boussac, A., Rutherford, W. 2002. Photosystem II and photosynthetic oxidation of water: an overview. Phil. Trans. R. Soc. Lond. B 357, 1369-1381.

Guest, C., Schulze, D., Thompson, I., Huber, D. 2002. Correlating manganese $\mathrm{X}$-ray absorption near-edge structure spectra with extractable soil manganese. Soil Sci. Soc. Am. J. $66,1172-1181$

Hall, J.L. 2002. Cellular mechanisms for heavy metal detoxification and tolerance. J. Exp. Bot. $53,1-11$.
Hauck, M., Paul, A., Gross, S., Raubuch, M. 2003. Manganese toxicity in epiphytic lichens: chlorophyll degradation and interaction with iron and phosphorus. Environ. Exp. Bot. 49, 181-191.

Hegedüs, A., Erdei, S., Horváth, G. 2001. Comparative studies of $\mathrm{H}_{2} \mathrm{O}_{2}$ detoxifying enzymes in green and greening barley seedlings under cadmium stress. Plant Sci. 160, 10851093.

Henriques, F. 2003. Gas exchange, chlorophyll a fluorescence kinetics and lipid peroxidation of pecan leaves with varying manganese concentrations. Plant Sci. 165, 239-244.

Herren, T., Feller U. 1994. Transfer of zinc from xylem to phloem in the peduncle of wheat, J. Plant Nutr. 17, 1587-1598

Hirschi, K., Korenkov, V., Wilganowski, N., Wagner, G.J. 2000. Expression of Arabidopsis CAX2 in tobacco. Altered metal accumulation and increased manganese tolerance. Plant Physiol. 124, 125-133.

Horiguchi, T. 1987. Mechanism of manganese toxicity and tolerance of plants. II. Deposition of oxidized manganese in plant tissues. J. Soil Sci. Plant Nutr. 33, 595-606.

Horst, W.J. 1988. The physiology of manganese toxicity. In: R.D. Graham, R.J. Hannam, N.J. Uren (eds). Manganese in Soil and Plants. Kluwer Academic Publishers, Dordrecht, The Netherlands, pp. 175-188.

Horst, W., Fecht, M., Naumann, A., Wissemeier, A., Maier, P. 1999. Physiology of manganese toxicity and tolerance in Vigna unguiculata (L.) Walp. J. Plant Nutr. Soil Sci. 162, 263-274.

Houtz, R.L., Nable, R.O., Cheniae, G.M. 1988. Evidence for effects on the in vivo activity of ribulose-biphosphate carboxylase/oxygenase during development of $\mathrm{Mn}$ toxicity in tobacco. Plant Physiol. 86, 1143-1149.

Hue, N. 1988. A possible mechanism for manganese toxicity in Hawaii soils amended with a low-Mn sewage sludge. J Environ. Qual. 17, 473-479.

Hue, N., Mai, Y. 2002. Manganese toxicity in watermelon as affected by lime and compost amended to a Hawaiian acid Oxisol. Hortscience $37,656-661$. 
Humphries, J., Stangoulis, J., Graham, R. 2007. Manganese. In: A. Barker, D. Pilbeam (eds). Handbook of Plant Nutrition, Taylor and Francis, USA, pp. 351-366.

Iwasaki, K., Maier, P., Fecht, M., Horst, W. 2002. Effects of silicon supply on apoplastic manganese concentrations in leaves and their relation to manganese tolerance in cowpea (Vigna unguiculata (L.)Walp). Plant Soil 238, 281-288.

Kochian, L., Hoekenga, O., Piñeros, M. 2004 How do crops plants tolerate acid soils? Mechanisms of aluminum tolerance and phosphorus efficiency. Annu. Rev. Plant Biolog. $55,459-93$

Kogelmann, W., Sharpe, W. 2006. Soil acidity and manganese in declining and nondeclining sugar maple stands in Pennsylvania. J. Environ. Qual. 35, 433-441.

Korshunova, Y., Eide, D., Clark, W., Guerinot, M., Pakrasi, H. 1999. The IRT1 protein from Arabidopsis thaliana is a metal transporter with a broad substrate range. Plant Mol. Biol. 40, 37-44.

Laha, S., Luthy, R. 1990. Oxidation of aniline and other primary aromatic amines by manganese dioxide. Environ. Sci. Technol. 24, 363-373.

Lavres J., Malavolta, E., Nogueira, N.L., Moraes, M.F., Rodrigues, A., Lanzoni, M., Pereira, C. 2009. Changes in anatomy and root cell ultrastructure of Soybean genotypes under manganese stress. R. Bras. Ci. Solo 33,395-403.

Lei, Y., Korpelainen, H., Li, C. 2007. Physiological and biochemical responses to high Mn concentrations in two contrasting Populus cathayana populations. Chemosphere 68,686 694.

Lidon, F. 2001. Tolerance of rice to excess manganese in the early stages of vegetative growth. Characterization of manganese accumulation. J. Plant Physiol. 158, 1341-1348.

Lidon, F.C., Barreiro, M., Ramalho, J. 2004. Manganese accumulation in rice: implications for photosynthetic functioning. J. Plant Physiol. 161, 1235-1244.

Lidon, F.C, Teixeira, M.G. 2000a. Rice tolerance to excess $\mathrm{Mn}$ : Implications in the chloroplast lamellae and synthesis of a novel $\mathrm{Mn}$ protein. Plant Physiol. Biochem. 38, 969-978.

Lidon, F.C., Teixeira, M.G. 2000b. Oxy radicals production and control in the chloroplast of Mn-treated rice. Plant Sci.152, 7-15.
Lidon, F.C., Henriques, F. 1993. Oxygen metabolism in higher plant chloroplasts. Photosynthetica 29, 249-279.

Luk, E., Jensen, L.T., Culotta, V.C. 2003. The many highways for intracellular trafficking of metals. JBIC 8, 803-809.

Lynch, J.P., St.Clair, S.B. 2004. Mineral stress: the missing link in understanding how global climate change will affect plants in real world soils. Field Crop. Res. 90, 101-115.

Ma, J.F. Ryan, P. R., Delhaize, E. 2001. Aluminium tolerance in plants and the complexing role of organic acids. Trends Plant Sci. 6, 273-278.

Maas E., Moore D. 1968. Manganese absorption by excised barley roots. Plant Physiol. 43, 527530 .

McCain, D.C., Markley, J:L. 1989. More manganese accumulates in maple sun leaves than in shade leaves. Plant Physiol. 90: 1417-1421.

Macfie, S., Taylor, G. 1992. The effects of excess manganese on photosynthetic rate and concentration of chlorophyll in Triticum aestivum grown in solution culture. Physiol. Plant. 85, 467475.

Macfie, S., Cossins, E., Taylor, G. 1994. Effects of excess manganese on production of organic acids in Mn-tolerant and in Mn-sensitive cultivars of Triticum aestivum L. (wheat). J. Plant Physiol. 143, 135-144.

Marschner, H. 1991. Mechanisms of adaptation of plants to acid soils. In: R. Wright, V. Baligar, R. Murrmann (Eds). Development in Plant and Soil Sciences. Plant-soil interactions at low $\mathrm{pH}$. Kluwer Academic Publisher, West Virginia, pp. $1-20$.

Marschner, H. 1995. Mineral Nutrition of Higher Plants. Academic Press, San Diego, 889 $\mathrm{p}$

Martinoia, E., Klein, M., Geisler, M., Bovet, L., Forestier, C., Kolukisaoglu, H., MuellerRoeber, B., Schulz, B. 2002. Multifunctionality of plant $\mathrm{ABC}$ transporters: more than just detoxifiers. Planta 214, 345-355.

Migocka M., Klobus G. 2007. The properties of the $\mathrm{Mn}, \mathrm{Ni}$ and $\mathrm{Pb}$ transport operating at plasma membranes of cucumber roots. Physiol. Plant. 129, 578-587.

Mills, R., Doherty, M., López-Marqués, R., Weimar, T., Dupree, P., Palmgren, M., 
Pittman, J., Williams, L. 2008. ECA3, a Golgilocalized P2A-type ATPase, plays a crucial role in manganese nutrition in Arabidopsis. Plant Physiol. 146, 116-128.

Miner, G., Sims, J. 1983. Changing fertilization practices and utilization of added plant nutrient for efficient production of tobacco. Recent Adv. Tobacco Sci. 9, 4-76.

Mitsukawa, N., Okumura, S., Shirano, Y., Sato, S., Kato, T., Harashima, S., Shibata, D. 1997. Overexpression of an Arabidopsis thaliana high-affinity phosphate transporter gene in tobacco cultured cells enhances cell growth under phosphate-limited conditions. Proc. Natl. Acad. Sci. 94, 7098-7102.

Mora, M., Alfaro, M., Jarvis, S., Demanet, R., Cartes, P. 2006. Soil aluminium availability in Andisols of southern Chile and its effect on forage production and animal metabolism. Soil Use Manage. 22, 95-101

Mora, M., Rosas, A., Ribera, A., Rengel, R. 2009. Differential tolerance to $\mathrm{Mn}$ toxicity in perennial ryegrass genotypes: involvement of antioxidative enzymes and root exudation of carboxylates. Plant Soil 320, 79-89.

Moroni, J., Scott, B., Wratten, N. 2003. Differential tolerance of high manganese among rapseed genotypes. Plant Soil 253, 507-519.

Mukhopadhyay M., Sharma, A. 1991. Manganese in cell metabolism of higher plants Bot. Rev. 57, 117-149.

Nable, R., Houtz, R. Cheniae, G. 1988. Early inhibition of photosynthesis during development of Mn toxicity in tobacco. Plant Physiol. 86, 1136-1142.

Najeeb, U., Xu, L., Shafaqat, A., Jilani, G., Gong, H.J., Shen, W.Q., Zhou, W.J. 2009 Citric acid enhances the phytoextraction of manganese and plant growth by alleviating the ultrastructural damages in Juncus effusus L. J. Hazard. Mater. 170, 1156-1163.

Ness, P.J., Woolhouse, H.W. 1980. RNA synthesis in Phaseolus chloroplasts. 1. Ribonucleic acid synthesis and senescing leaves. J. Exp. Bot. 31, 223-233.

Neumann, G., Romheld, V. 2001. The release of root exudates as affected by the plants physiological status. In: R. Pinto, Z. Varanini, P. Nannipieri (eds). The rhizosphere: Biochemistry and organic substances at the soil-plant interface, Marcel Dekker. New York, pp. 41-93.
Page, V., Feller, U. 2005. Selective transport of zinc, manganese, nickel, cobalt and cadmium in the root system and transfer to the leaves in young wheat plants. Ann. Bot. 96, 425-434.

Page, V., Weisskopf, L., Feller, U. 2006. Heavy metals in white lupin: uptake, root-to-shoot transfer and redistribution within the plant. New Phytol. 171, 329-341.

Panda, S., Mishra, A.K., Biswal, U.C. 1986. Manganese-induced modification of membrane lipid peroxidation during aging of isolated wheat chloroplasts. Photobiochem. Photobiophys 13, 53-61.

Papadakis, I., Giannakoula, A., Therios, I., Bosabalidis, A., Moustakas, M., Nastou, A. 2007. Mn-induced changes in leaf structure and chloroplast ultrastructure of Citrus volkameriana (L.) plants. J. Plant Physiol. 164, 100-103.

Pendias, K., Pendias, H. 1992. Trace elements in soils and plants. USA, CRR Press, $365 \mathrm{p}$.

Pfeffer, P.E., Tu, S., Gerasimowicz, W.V., Cavanaugh, J.R. 1986. In vivo 31P NMR studies of corn root tissue and its uptake of toxic metals. Plant Physiol. 80, 77-84.

Pittman, J. 2005. Managing the manganese: molecular mechanisms of manganese transport and homeostasis. New Phytol. 167, 733-742.

Polle, A. 2001. Dissecting the superoxide dismutase-ascorbate-glutathione-pathway in chloroplasts by metabolic modeling. Computer simulations as a step towards flux analysis. Plant Physiol. 126, 445-462.

Porter, G., Bajita-Locke, J., Hue, N., Strand, S. 2004. Manganese solubility and phytotoxicity affected by soil moisture, oxygen levels, and green manure additions. Comm. Soil Sci. Plant. Anal. 35, 99-116.

Reddi, A.R., Jensen, L.T., Culotta, V.C. 2009. Manganese homeostasis in Saccharomyces cerevisiae. Chem. Rev. 109, 4722-4732.

Rengel, Z. 2000. Uptake and transport of manganese in plants. In: A. Sigel, H. Sigel (eds.) Metal Ions in Biological Systems. New York, Marcel Dekker, pp. 57-87.

Rengel, Z. 2001. Xylem and phloem transport of micronutrients. In: W. J. Horst et al.(eds). Plant nutrition - Food security and sustainability of agro-ecosystems. Kluwer Academic Publishers, Netherlands, pp. 628-629. 
Rengel, Z., Marschner, P. 2005. Nutrient availability and management in the rhizosphere: exploiting genotypic differences. New Phytol. 168, 305-312.

Roberts, L., Pierson, A., Panaviene, Z., Walker, E. 2004. Yellow Stripe 1. Expanded roles for the maize iron-phytosiderophore transporter. Plant Physiol. 135, 112-120.

Rosas, A., Rengel, Z., Mora, M. 2007. Manganese supply and $\mathrm{pH}$ influence growth, carboxylate exudation and peroxidase activity of ryegrass and white clover. J. Plant Nutr.30, 253270.

Ryan, P., Delhaize, E., Jones, D. 2001. Function and mechanism of organic anion exudation from plant roots. Annu. Rev. Plant Physiol. Plant Mol. Biol. 52, 527-560.

Sarkar, D., Pandey, S., Sud, K., Chanemougasoundharam, A. 2004. In vitro characterization of manganese toxicity in relation to phosphorus nutrition in potato (Solanum tuberosum L.). Plant Sci. 167, 977-986.

Shi, Q., Bao, Z., Zhu, Z., He, Y., Qian, Q., Yu, J. 2005. Silicon-mediated alleviation of $\mathrm{Mn}$ toxicity in Cucumis sativus in relation to activities of superoxide dismutase and ascorbate peroxidase. Phytochemistry 66, 1551-1559.

Shi, Q., Zhu, Z., Xu, M., Qian, Q.,Yu, J. 2006. Effect of excess manganese on the antioxidant system in Cucumis sativus L. under two light intensities. Environ. Exp. Bot. 58, 197-205.

Shigaki, T., Pittman, J., Hirschi, K. 2003. Manganese specificity determinants in Arabidopsis metal/ $\mathrm{H}+$ antiporter CAX2. J. Biol Chem. 21, 6610-6617.

Sparks, D. 1995. Environmental Soil Chemistry. San Diego, Academic Press, 352 p.

Sparrow, L., Uren, N. 1987. Oxidation and reduction of $\mathrm{Mn}$ in acidic soils: effect of temperature and soil pH. Soil Biol. Biochem. 19, 143-148.

Takahashi, M., Sugiura, M. 2001. Strategies for uptake of a soil micronutrient, manganese, by plant roots. RIKEN Review 35, 76-77.

Tsuji, M., Mori, H., Yamamoto, T., Tanaka, S., Kang, Y., Sakurai, K., Iwasaki, K. 2006. Manganese toxicity of melon plants growing on an isolated soil bed after steam sterilization. J. Soil Sci. Plant Nutr. 77, 257-263.
Thomine, S., Lelievre, F., Debarbieux, E., Schroeder, J., Barbier-Brygoo, H. 2003. AtNRAMP3, a multispecific vacuolar metal transporter involved in plant responses to iron deficiency. Plant J. 34, 685-695.

Wang, Y., Wisniewski, M., Meilan, R., Uratsu, S., Cui, M., Dandekar, A., Fuchigami, L. 2007. Ectopic expression of Mn-SOD in Lycopersicon esculentum leads to enhanced tolerance to salt and oxidative stress. J. Applied Hortic. 9, 3-8.

Wang, Y., Ying, Y., Chen, J.,Wang, X. 2004. Transgenic Arabidopsis overexpressing Mn-SOD enhanced salt-tolerance. Plant Sci. 167, 671-677.

Watmough, S., Eimer, M., Dillon, P. 2007. Manganese cycling in central Ontario forests: Response to soil acidification. Appl. Geochem. 22, 1241-1247.

Wissemeier, A., Horst, W. 1991. Simplified methods for screening cowpea cultivars for manganese leaf-tissue tolerance. Crop Sci. 31, $435-439$.

Wissemeier A., Horst, W. 1992. Effect of light intensity on manganese toxicity symptoms and callose formation in cowpea (Vigna unguiculata (L.) Walp.). Plant Sci. 143, 299-309.

Wu, Z., Liang, F., Hong, B., Young, J.C., Sussman, M.R., Harper, J.F., Sze, H. 2002. An endoplasmic reticulum-bound $\mathrm{Ca}^{2+} / \mathrm{Mn}^{2+}$ pump, ECA1, supports plant growth and confers tolerance to $\mathrm{Mn}^{2+}$ stress. Plant Physiol. 130, 128 137.

Yang, X.E., Baligar, V.C., Foster, J.C., Martens, D.C. 1997. Accumulation and transport of nickel in relation to organic acids in ryegrass and maize grown with different nickel levels. Plant Soil 196: 271-276.

Zouni, A., Witt, H., Kern, J., Fromme, P., Kraub, N., Saenger, W., Orth, P. 2001. Crystal structure of photosystem II from Synechococcus elongatus at $3.8 \AA$ resolution. Nature 409, 739743. 